\title{
Factors Driving Energy-Related Carbon Emissions in Xinjiang: Applying the Extended STIRPAT Model
}

\author{
Changjian Wang ${ }^{1 *}$, Bin Wen², Fei Wang ${ }^{3 *}$, Lixia Jin ${ }^{1}$, Yuyao Ye ${ }^{1 * *}$ \\ ${ }^{1}$ Guangdong Open Laboratory of Geospatial Information Technology and Application, \\ Guangzhou Institute of Geography, Guangzhou 510070, China \\ ${ }^{2}$ College of Economic and Management, Huanghuai University, Zhumadian 463000, China \\ ${ }^{3}$ School of Geography Science and Tourism, Xinjiang Normal University, Urumqi 830054, China
}

Received: 26 September 2016

Accepted: 13 February 2017

\begin{abstract}
To achieve emission reduction targets in China, it is necessary to analyze the factors driving energyrelated carbon emissions from a regional perspective. We used extended STIRPAT model (stochastic impacts by regression on population, affluence, and technology) based on the classical IPAT identity (where $\mathrm{I}=$ impact representing carbon emissions, $\mathrm{P}=$ population, $\mathrm{A}=$ affluence, and $\mathrm{T}=$ emission intensity) to determine the main factors driving energy-related carbon emissions in Xinjiang from 1952 to 2014, an important Chinese energy base in northwestern China. Total carbon emissions in Xinjiang were found to increase from $28.51 \times 10^{4} \mathrm{t}$ in 1952 to $9,446.61 \times 10^{4} \mathrm{t}$ in 2014 , representing a 331.34 -fold increase over a period of 63 years. Results show that the impacts and influences of various factors on carbon emissions varied among three stages of development: "Before Reform and Opening up" (1952-1977), "After Reform and Opening up" (1978-2000), and "Western Development" (2001-2014). In the first stage, emission intensity and population size were the dominant contributors to increments in carbon emissions, while the energy consumption structure played an important role in curbing carbon emissions. In the second stage, economic growth and population size were the dominant contributors to increments in carbon emissions, while emission intensity had a significant negative effect on carbon emissions. In the third stage, fixed asset investment and economic growth were the dominant contributors to increments in carbon emissions, while emission intensity had a significant negative effect on carbon emissions.
\end{abstract}

Keywords: energy consumption, carbon emissions, IPAT, STIRPAT, Xinjiang

\footnotetext{
*e-mail: wwwangcj@126.com, wangfei09@mails.ucas.ac.cn

**e-mail: yeyuyao@gdas.ac.cn
} 


\section{Introduction}

Controlling greenhouse gas emissions and curbing global warming have become priorities in developing strategies for a sustainable future [1-4]. China, the biggest emerging and developing country, has become the world's largest $\mathrm{CO}_{2}$ emitter after decades of rapid economic growth. The carbon emissions problem is now receiving extensive and sustained interest of government policy makers, industrial manufacturers, and researchers because of pressure from public opinion derived from international climate negotiations; furthermore, to address resource and environmental constraints, domestic energy consumption should be reduced and conserved [5-8]. Under these circumstances, the Chinese government released a binding reduction target to achieve peak carbon emissions before 2030 [9]. The importance and urgency of research on carbon emissions is becoming increasingly evident in light of concerns regarding whether promises to mitigate carbon emissions could be fulfilled with a binding force while simultaneously maintaining stable development of the social economy. Therefore, in-depth studies on the factors driving energy-related carbon emissions in China need to be conducted [10-12]. In particular, such studies should be carried out at the regional and provincial levels because there are wide differences in development models, economic structure, consumption levels, available technology, residential lifestyles, and resource endowment across different provinces within China [13-14]. Presently, curbing carbon emissions without significantly affecting social-economic development is a serious issue faced by local governments, particularly in the underdeveloped regions of northwestern China [10-11].

Most research on factors influencing carbon emissions have focused mainly on population (population size and population structure), economy (economic growth and economic structure), and energy (energy consumption and energy technology), among others [15-18]. Li et al. conducted an analysis based on the STIRPAT (stochastic impacts by regression on population, affluence, and technology) method and reported that GDP per capita, industrial structure, population, urbanization level, and technology level were the major factors influencing China's $\mathrm{CO}_{2}$ emissions [19]. Zhang et al. adopted an econometric model and their research indicated that financial developments and foreign direct investments (FDI) significantly influenced the increase in carbon emissions in China [20]. Using provincial panel data, Zhou et al. found that industrial structural adjustment was an important component of the low-carbon economy in China [21]. Based on regional analysis, Tian et al. found that the disparity in regional industrial structure impacted regional carbon emissions substantially in China [22]. Using the STIRPAT model, Li et al. further found that GDP per capita, industrial structure, population, urbanization, and technology level had different impacts on carbon emissions in different regions in China [23].

The aims of this case study were to analyze energyrelated carbon emissions and to determine the most important factors driving increments in carbon emissions in Xinjiang. Our estimates were based on national and provincial statistics, including population (population size and population structure), economy (gross domestic product, industrial structure, and fixed assets investment), and energy (total energy consumption and energy consumption structure) from 1952 to 2014. Energyrelated carbon emissions were calculated according to the method mentioned in the IPCC Guidelines for National Greenhouse Gas Inventories. In order to understand the factors driving carbon emissions during 1952-2014 in detail, we divided the process into three stages: "Before Reform and Opening up" (1952-1977), "After Reform and Opening up" (1978-2000), and "Western Development" (2001-2014).

Compared to previous works, the innovation and contribution of this study mainly lies in the following two aspects. First, the factors affecting carbon emissions are more complex than that reported by relevant carbon emissions research previously conducted in Xinjiang. Second, research on different regions involving comparative analysis of different development stages may provide different conclusions. Thus the aim of this work was to provide a theoretical framework to support making more-targeted policies on energy savings and emission reduction in Xinjiang.

\section{Material and Methods}

\section{Estimation of Carbon Emissions}

Carbon emissions from energy consumption were calculated according to the following method [10-12, 24], in which the carbon emissions factors and the conversion factor are as follows:

$$
C_{t}=\sum_{i} E_{t}^{i} \times L C V_{i} \times C F_{t}^{i} \times O_{i}
$$

...where the subscript $i$ is the type of fuel considered in this case study, $t$ means the time in years, $C_{t}$ represents total carbon emissions in year $t$ (in million tons, $\mathrm{Mt}$ ), $E_{t}^{i}$ represents the total energy consumption of fuel type $i$ in year $t$ (million tons of standard coal equivalent, Mtce), and $L C V_{i}$ is the lower calorific value of fuel $i . C F^{i}{ }_{t}$ is the carbon emissions factor of the fuel type $i$, and $O_{i}$ is the oxidation rate of fuel $i$.

\section{STIRPAT Model Construction}

The IPAT (impact $=$ population $\times$ affluence $\times$ technology) identity was established by Ehrlich and Holden in the early 1970s [25-26], and is regarded as an easily understandable framework for measuring the factors driving environmental pressure [13], which can be described with the following equation: 


$$
I=P A T
$$

... where $I$ represents the environmental pressure indicator (i.e., carbon emissions in this case study), $P$ is population, $A$ is affluence, and $T$ is technology.

In the IPAT model, $I$ was influenced by the driving factors ( $P, A$, and $T$, respectively). However, the IPAT identity has been criticized for certain limitations in the proportional relationship between influencing factors and environmental pressure indicators. York et al. established the STIRPAT model with a stochastic form on the basis of the IPAT framework $[27,28]$, which is described as follows:

$$
I=a P^{b} A^{c} T^{d} e
$$

... where $I, P, A$, and $T$ have the same meanings as those in Eq. (2), $a$ represents the model coefficient; $b, c$, and $d$ represent the exponents for independent variables; and $e$ represents the model error term. The introduction of $b, c$, and $d$ compensate the model deficiency that $I$ was equally proportional to the various driving forces. This can be used to analyze the case of non-proportional influence of various independent variables on the environmental pressure [29].

The STIRPAT model is a multivariable nonlinear model [29]. By taking the natural logarithm on both sides of Eq. (3), it can be expressed as:

$$
L n I=a+b \operatorname{Ln} P+c \operatorname{Ln} A+d \operatorname{Ln} T+\operatorname{Lne}
$$

In the newly established STIRPAT model, more influential factors can be introduced for analyzing their influence on carbon emissions [13]. Regression coefficients are used to reflect the proportional relationship between driving factors and carbon emissions [30-33]. In order to further investigate the driving factors, a few more factors have been introduced to explain changes in carbon emissions. On the basis of the total population $(P)$, the urbanization level $[15,34]\left(P_{c}\right)$, which is represented by the proportion of the urban population, was introduced to analyze the influence on carbon emissions. Affluence $(A)$, which is represented by the GDP per capita, is used to analyze the influence of economic growth on carbon emissions. $T$ is characterized using the carbon emissions per unit GDP, which represents the influence of technological progress on carbon emissions [10, 12]. $S I$ (industrialization) and $V$ (total fixed assets investment) are used to study the influence of changes in the industrial structure and investment on carbon emissions [17-18, 34]. Factor $E$ (energy consumption structure) is introduced to study the influence of changes in the energy consumption structure on carbon emissions [16]. The explanations of the specific variables are listed in Table 1, and are related in the following equation as follows:

$$
\begin{aligned}
\operatorname{LnI}= & a+b_{1} \operatorname{Ln} P_{s}+b_{2} \operatorname{Ln} P_{c}+c \operatorname{Ln} A+d \operatorname{Ln} T \\
& +e_{1} \operatorname{LnSI}+v \operatorname{Ln} V+f \operatorname{Ln} E+\operatorname{Lne}
\end{aligned}
$$

\section{Results and Discussion}

\section{Energy-Related Carbon Emission Revolution Process}

According to the calculation results, energy-related carbon emissions increased from $28.51 \times 10^{4} \mathrm{t}$ in 1952 to $9446.11 \times 10^{4}$ tons in 2014 in Xinjiang (Fig. 1), which amounts to an increase by 331.33 times in the span of 63 years. There were fluctuations in carbon emissions during the period before the Reform and Opening-up (1952-1977), with increases from $28.51 \times 10^{4} \mathrm{t}$ in 1952 to $631.31 \times 10^{4} \mathrm{t}$ in 1977 , at an annual growth rate of $12.43 \%$. Carbon emissions increased from $674.71 \times 10^{4} \mathrm{t}$ in 1978 to $2,174.57 \times 10^{4}$ t in 2000 during the period after the Reform and Opening-up (1978-2000), with an annual growth rate of $5.22 \%$. Xinjiang's regional economy grew rapidly during the period of Western Development (2001-14), and carbon emissions increased similarly, from 2,245.59 $\times 10^{4} \mathrm{t}$ in 2001 to $9,446.11 \times 10^{4} \mathrm{t}$ in 2014 , at an annual growth rate of $10.81 \%$.

Table 1. Description of variables used in the analysis during 1952 to 2014.

\begin{tabular}{|c|c|c|c|}
\hline Variables & Symbol & Definition measuring method & Unit \\
\hline Carbon emissions & I & Energy-related carbon emission accounting & Motal population \\
\hline Population size & Ps & Percentage of urban population in total population & $\%$ \\
\hline Urbanization & Pc & Gross domestic product divided by population & Yuan per captia \\
\hline Economic growth & A & Carbon emissions per unit gross domestic product & t/10000 Yuan \\
\hline Technological progress & T & GDP & $\%$ \\
\hline Industrialization & SI & Proportion of the secondary industry output value over total & Billion Yuan \\
\hline Fixed assets investment & V & Total fixed assets investment & $\%$ \\
\hline Energy consumption structure & E & Percentage of coal consumption to total energy consumption & . \\
\hline
\end{tabular}




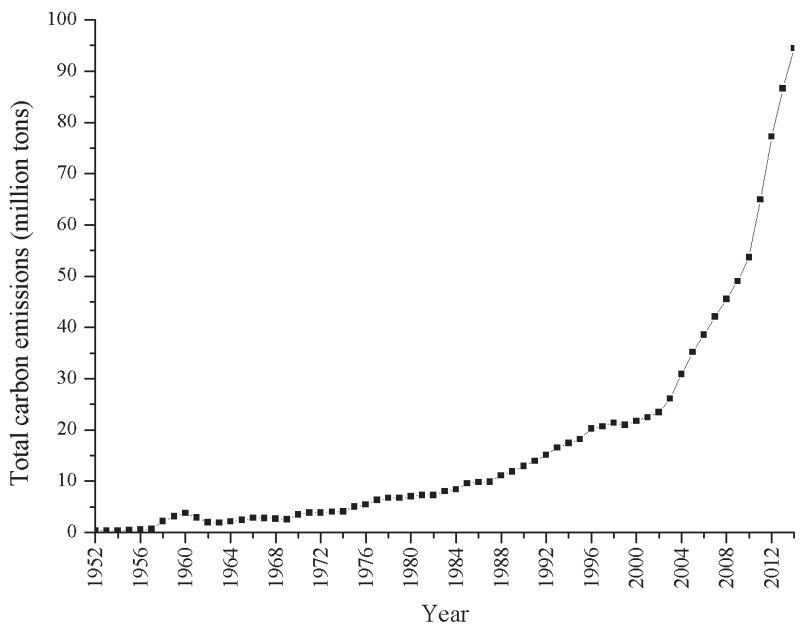

Fig. 1. Total carbon emissions changes in Xinjiang from 1952 to 2014 .

As shown in Figs 2-5, the total population in Xinjiang grew 3.94 times from $465.17 \times 10^{4}$ in 1952 to $2,298.47 \times$ $10^{4}$ in 2014. The population of Xinjiang had been growing steadily, while the proportion of its total population to that of the national total population grew from $0.83 \%$ in 1952 to $1.65 \%$ in 2014 . The level of urbanization in Xinjiang increased from $16.04 \%$ in 1952 to $46.07 \%$ in 2014 , with an improvement of $27.96 \%$. Economic growth in Xinjiang was represented by GDP per capita, and the GDP data was converted into 1952 constant prices in order to improve comparability. The economic scale grew from 0.791 billion Yuan (B-CNY) in 1952 to 139.78 B-CNY in 2014 (at 1952 prices). The GDP per capita grew from 170.05 CNY per capita in 1952 to 6081.74 CNY per capita in 2014, which was 35.76 times that in 1952. In this study, changes in the proportion of coal consumption was used to characterize the evolution of the energy consumption structure, while technological progress was represented by carbon emissions per unit GDP. The proportion of coal consumption in Xinjiang had an overall declining trend.

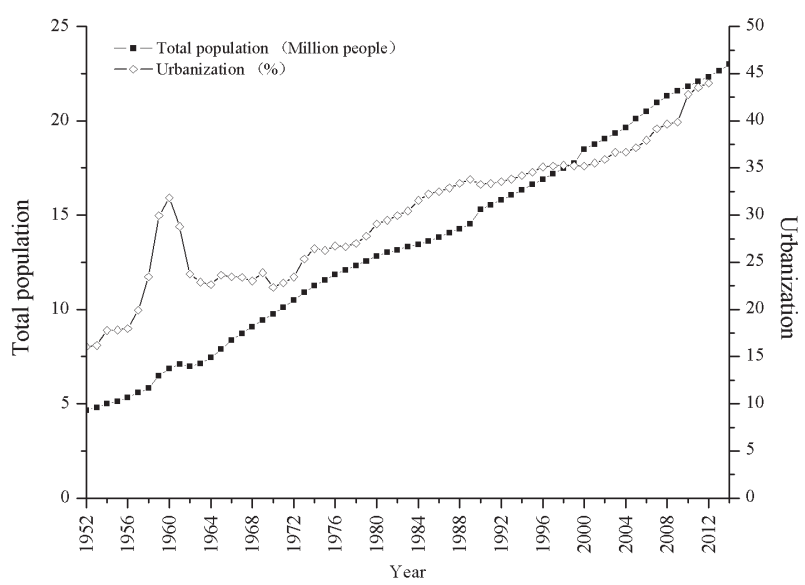

Fig. 2. Changes of total population and urbanization in Xinjiang from 1952 to 2012 .

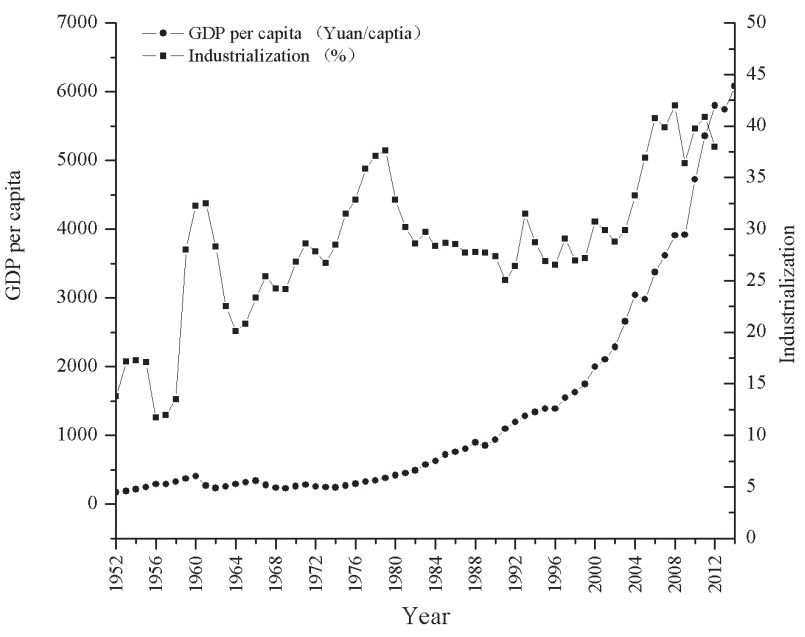

Fig. 3. Changes of economic growth and industrialization levels in Xinjiang from 1952 to 2012.

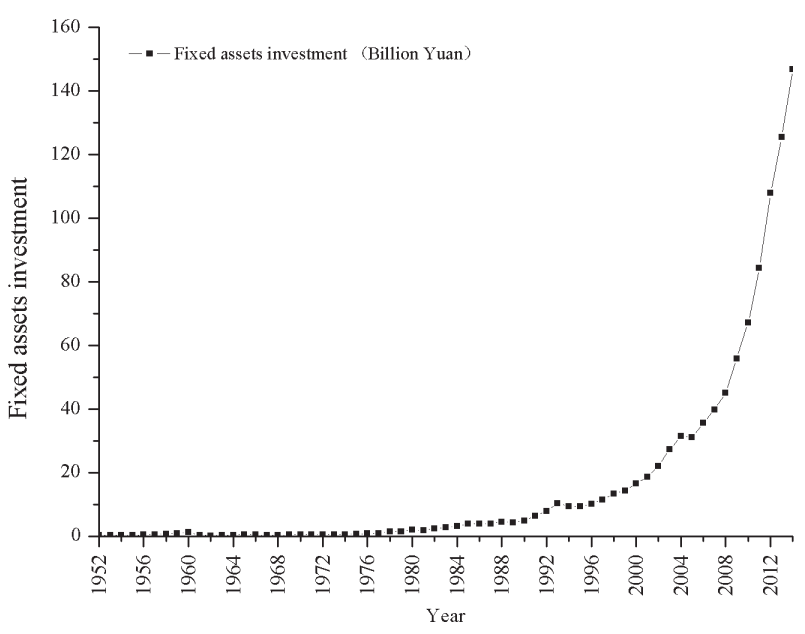

Fig. 4. Changes of fixed assets investment in Xinjiang from 1952 to 2014 .

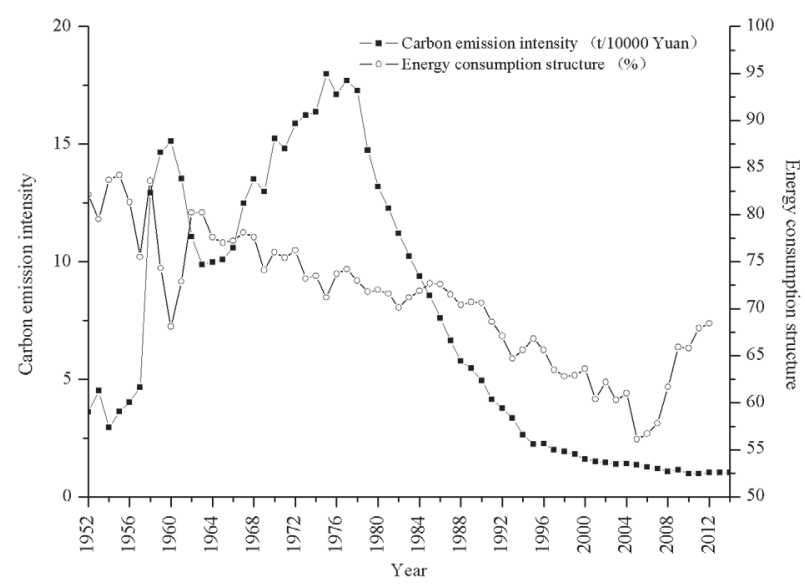

Fig. 5. Changes of carbon emissions intensity and energy consumption structure in Xinjiang from 1952 to 2014. 
The trends of change in technological progress showed an inverted "V" shape (when the staged peaks in the period of the "Great Leap Forward" during 1958-1960 were excluded). There were periods of growth followed by periods of decline, with the turning point at approximately 1978.

During the period prior to the Reform and Openingup (1952-1977) stage, the population in Xinjiang had grown rapidly owing to a loose policy on population. There were two peak birth periods in Xinjiang in the 1960s and $1970 \mathrm{~s}$. The total population grew from $465.17 \times 10^{4}$ in 1952 to $1,208.97 \times 10^{4}$ in 1977 at an average annual growth rate of $3.82 \%$, making it one of the provinces with the fastest population growth in China. The urbanization level had been growing with fluctuations from $16.04 \%$ in 1952 to $26.64 \%$ in 1977 . The economy had been growing slowly, with an average annual growth rate of $2.59 \%$ in the GDP per capita. Excluding the abnormal fluctuations during the "Great Leap Forward" (1958-1960), the industrialization level in Xinjiang improved rapidly (at an average annual growth rate of $3.90 \%$ ), and grew from $13.78 \%$ in 1952 to $35.86 \%$ in 1977 . However, the total amount of fixed assets investment in Xinjiang had been low. The energy consumption structure in Xinjiang had been mainly based on coal and oil. The proportion of coal consumption was adjusted, with fluctuations from $82.1 \%$ in 1952 to $74.2 \%$ in 1977 . During the same period, carbon emissions per ten thousand CNY of GDP showed a trend of increase owing to the extensive utilization of fossil energy.

After the Reform and Opening-up (1978-2000) stage, the population growth rate slowed down with the

Table 2. Correlation test results.

\begin{tabular}{|c|c|c|c|c|c|c|c|c|c|}
\hline & LnI & \multicolumn{2}{|c|}{ LnPs } & $\mathrm{LnPc}$ & LnA & $\mathrm{LnT}$ & LnSI & $\mathrm{LnV}$ & $\mathrm{LnE}$ \\
\hline \multicolumn{10}{|c|}{ 1. Matrix of correlation between variables (1952-77) } \\
\hline LnI & 1 & \multicolumn{2}{|c|}{$.896^{* *}$} & $.809^{* *}$ & $.524^{* *}$ & $.981^{* *}$ & $.835^{* *}$ & $.636^{* *}$ & $-.734^{* *}$ \\
\hline LnPs & $.896^{* *}$ & \multicolumn{2}{|c|}{1} & $.564^{* *}$ & .200 & $.855^{* *}$ & $.794^{* *}$ & $.488^{* *}$ & $-.655^{* *}$ \\
\hline $\mathrm{LnPc}$ & $.809^{* *}$ & \multicolumn{2}{|c|}{$.564^{* *}$} & 1 & $.746^{* *}$ & $.779^{* *}$ & $.756^{* *}$ & $.723^{* *}$ & $-.713^{* *}$ \\
\hline LnA & $.524^{* *}$ & \multicolumn{2}{|c|}{.200} & $.746^{* *}$ & 1 & $.434^{*}$ & .347 & $.616^{* *}$ & $-.407^{*}$ \\
\hline $\operatorname{LnT}$ & $.981^{* *}$ & \multicolumn{2}{|c|}{$.855^{* *}$} & $.779^{* *}$ & $.434^{*}$ & 1 & $.822^{* *}$ & $.580^{* *}$ & $-.715^{* *}$ \\
\hline LnSI & $.835^{* *}$ & \multicolumn{2}{|c|}{$.794^{* *}$} & $.756^{* *}$ & .347 & $.822^{* *}$ & 1 & $.454^{*}$ & $-.722^{* *}$ \\
\hline $\mathrm{LnV}$ & $.636^{* *}$ & \multicolumn{2}{|c|}{$.488^{* *}$} & $.723^{* *}$ & $.616^{* *}$ & $.580^{* *}$ & $.454^{*}$ & 1 & $-.659^{* *}$ \\
\hline $\operatorname{LnE}$ & $-.734^{* *}$ & \multicolumn{2}{|c|}{$-.655^{* *}$} & $-.713^{* *}$ & $-.407^{*}$ & $-.715^{* *}$ & $-.722^{* *}$ & $-.659^{* *}$ & 1 \\
\hline \multicolumn{10}{|c|}{ 2. Matrix of correlation between variables (1978-2000) } \\
\hline LnI & \multicolumn{2}{|l|}{1} & $.991^{* *}$ & $.777^{* *}$ & $.998^{* *}$ & $-.994^{* *}$ & $-.539^{* *}$ & $.996^{* *}$ & $-.915^{* *}$ \\
\hline LnPs & $.991^{* *}$ & & 1 & $.719^{* *}$ & $.993^{* *}$ & $-.994^{* *}$ & $-.529^{* *}$ & $.993^{* *}$ & $-.929^{* *}$ \\
\hline $\mathrm{LnPc}$ & $.777^{* *}$ & & $.719^{* *}$ & 1 & $.775^{* *}$ & $-.763^{* *}$ & $-.748^{* *}$ & $.764^{* *}$ & $-.556^{* *}$ \\
\hline $\operatorname{Ln} A$ & $.998^{* *}$ & & $.993^{* *}$ & $.775^{* *}$ & 1 & $-.999^{* *}$ & $-.552^{* *}$ & $.998^{* *}$ & $-.916^{* *}$ \\
\hline $\operatorname{LnT}$ & $-.994^{* *}$ & & $-.994^{* *}$ & $-.763^{* *}$ & $-.999^{* *}$ & 1 & $.555^{* *}$ & $-.997^{* *}$ & $.919^{* *}$ \\
\hline LnSI & $-.539^{* *}$ & & $-.529^{* *}$ & $-.748^{* *}$ & $-.552^{* *}$ & $.555^{* *}$ & 1 & $-.540^{* *}$ & .329 \\
\hline $\mathrm{LnV}$ & $.996^{* *}$ & & $.993^{* *}$ & $.764^{* *}$ & $.998^{* *}$ & $-.997^{* *}$ & $-.540^{* *}$ & 1 & $-.928^{* *}$ \\
\hline $\operatorname{LnE}$ & $-.915^{* *}$ & & $-.929^{* *}$ & $-.556^{* *}$ & $-.916^{* *}$ & $.919^{* *}$ & .329 & $-.928^{* *}$ & 1 \\
\hline & & & 3. $\mathrm{N}$ & rix of correla & ation between va & ariables (2001 & 14) & & \\
\hline LnI & & & $.985^{* *}$ & $.987^{* *}$ & $.996^{* *}$ & $-.934^{* *}$ & $.582^{*}$ & $.996^{* *}$ & $.574^{*}$ \\
\hline LnPs & .98 & & 1 & $.986^{* *}$ & $.992^{* *}$ & $-.969^{* *}$ & $.660^{* *}$ & $.979^{* *}$ & $.546^{*}$ \\
\hline LnPc & .98 & & $.986^{* *}$ & 1 & $.994^{* *}$ & $-.963^{* *}$ & $.639^{*}$ & $.983^{* *}$ & $.586^{*}$ \\
\hline LnA & .99 & & $.992^{* *}$ & $.994^{* *}$ & 1 & $-.961^{* *}$ & $.615^{*}$ & $.993^{* *}$ & $.589^{*}$ \\
\hline $\operatorname{LnT}$ & -.9 & & $-.969^{* *}$ & $-.963^{* *}$ & $-.961^{* *}$ & 1 & $-.704^{* *}$ & $-.935^{* *}$ & $-.588^{*}$ \\
\hline LnSI & & & $.660^{* *}$ & $.639^{*}$ & $.615^{*}$ & $-.704^{* *}$ & 1 & $.523^{*}$ & .046 \\
\hline $\mathrm{LnV}$ & & & $.979^{* *}$ & $.983^{* *}$ & $.993^{* *}$ & $-.935^{* *}$ & $.523^{*}$ & 1 & $.622^{*}$ \\
\hline $\mathrm{LnE}$ & & & $.546^{*}$ & $.586^{*}$ & $.589^{*}$ & $-.588^{*}$ & .046 & $.622^{*}$ & 1 \\
\hline
\end{tabular}


implementation of the "One-child Policy" in Xinjiang. Total population grew from $1,233.01 \times 10^{4}$ in 1978 to $1,849.41 \times 10^{4}$ in 2000 at an average annual growth rate of $1.86 \%$. The urbanization level had been rapidly increasing at an average annual growth rate of $1.21 \%$, from $27.00 \%$ in 1978 to $35.21 \%$ in 2000 . The economy in Xinjiang had grown rapidly with the implementation of the "Reform and Opening-up Policy." GDP per capita increased at an average annual growth rate of $8.36 \%$. The industrialization level in Xinjiang had been declining with fluctuations at $37.06 \%$ in 1978 and $30.70 \%$ in 2000 . With the full implementation of the policy for internal reform and external opening-up, the total amount of fixed assets investment rapidly increased with an average annual growth rate of $11.87 \%$. With the increasing amounts of natural gas, hydropower, and wind power in the total energy consumption, the proportion of coal consumption decreased from $73.00 \%$ in 1978 to $63.6 \%$ in 2000 . During the same period, the carbon emissions per ten thousand CNY of GDP rapidly decreased at an average annual rate of $11.44 \%$ during $1978-2000$.

In the Western Development (2001-14) stage, the population in Xinjiang grew steadily at an average annual rate of $1.58 \%$ from $1,876.19 \times 10^{4}$ in 2001 to $2,298.47$ $\times 10^{4}$ in 2014. The urbanization level in Xinjiang had been accelerating at an average annual growth rate of $1.97 \%$ from $35.52 \%$ in 2001 to $46.07 \%$ in 2014 . With the implementation of the policy for "Western Development," the increase of GDP per capita accelerated with an average annual growth rate of $9.66 \%$ in Xinjiang. Furthermore, the industrialization level rapidly improved, and the change was accompanied by a clear trend of growth in the heavy chemical industry. The industrialization level grew, with fluctuations, from $29.87 \%$ in 2001 to $34.28 \%$ in 2014 . The total amount of fixed assets investment increased rapidly, at an annual average rate of $17.29 \%$. With the full implementation of the policy for Western Development, infrastructure construction such as for transportation and power, and heavy chemical industry for energy increased rapidly. The carbon emissions per ten thousand $\mathrm{CNY}$ of GDP significantly decreased at an average annual rate of $3.52 \%$. During this period, the proportion of coal consumption first declined from $60.40 \%$ in 2001 to $56.10 \%$ in 2005 , but then increased again to reach $65.1 \%$ in 2014.

\section{Analyses of the Regression Results}

Each variable was logarithmically processed before testing the correlation among them in order to eliminate the influence of variable dimensions [29]. It is evident from Table 2 that there were relatively high correlations among the variables Ps, Pc, A, T, SI, V, E, and I. Therefore, there might also be serious multicollinearity. In order to determine the multicollinearity between the dependent variable I and independent variables $\mathrm{Ps}, \mathrm{Pc}, \mathrm{A}, \mathrm{T}, \mathrm{SI}, \mathrm{V}$, and $\mathrm{E}$, the ordinary least square (OLS) estimation was first performed for each variable.
Table 3. OLS results.

\begin{tabular}{|c|c|c|c|c|}
\hline Variables & $\begin{array}{l}\text { Unstandar- } \\
\text { dized } \\
\text { coefficients }\end{array}$ & t-Statistic & Sig. & $\begin{array}{c}\text { Variance } \\
\text { inflation } \\
\text { factor }\end{array}$ \\
\hline \multicolumn{5}{|c|}{ 1. OLS results (1952-77) } \\
\hline $\mathrm{C}$ & -9.21034 & $-5.28 \mathrm{E}+08$ & 0 & \\
\hline LnPs & 1 & $1.28 \mathrm{E}+09$ & 0 & 16.053 \\
\hline $\mathrm{LnPc}$ & $1.57 \mathrm{E}-09$ & 0.927965 & 0.3651 & 19.612 \\
\hline LnA & 1 & $1.02 \mathrm{E}+09$ & 0 & 3.127 \\
\hline $\operatorname{LnT}$ & 1 & $2.12 \mathrm{E}+09$ & 0 & 17.322 \\
\hline LnSI & $-5.05 \mathrm{E}-10$ & -0.684057 & 0.5022 & 6.032 \\
\hline $\mathrm{LnV}$ & $8.87 \mathrm{E}-11$ & 0.237158 & 0.8151 & 3.090 \\
\hline $\mathrm{LnE}$ & 4.73E-09 & 1.432562 & 0.1682 & 3.022 \\
\hline $\mathrm{R}^{2}$ & 1.000 & & & \\
\hline Sig. & 0.000 & & & \\
\hline \multicolumn{5}{|c|}{ 2. OLS results (1978-2000) } \\
\hline $\mathrm{C}$ & -9.210341 & $-1.020 \mathrm{E}+08$ & 0 & \\
\hline LnPs & 1 & $9.027 \mathrm{E}+07$ & 0 & 158.973 \\
\hline $\mathrm{LnPc}$ & $-6.65 \mathrm{E}-10$ & $-4.299 \mathrm{E}-01$ & 0.6734 & 10.161 \\
\hline LnA & 1 & $2.700 \mathrm{E}+08$ & 0 & $1,309.359$ \\
\hline LnT & 1 & $2.410 \mathrm{E}+08$ & 0 & 848.641 \\
\hline LnSI & $2.63 \mathrm{E}-09$ & 1.323 & 0.2057 & 3.372 \\
\hline $\mathrm{LnV}$ & $8.30 \mathrm{E}-10$ & .537 & 0.5994 & 339.137 \\
\hline $\mathrm{LnE}$ & $9.77 \mathrm{E}-09$ & 1.258 & 0.2277 & 14.162 \\
\hline $\mathrm{R}^{2}$ & 1.000 & & & \\
\hline Sig. & 0.000 & & & \\
\hline \multicolumn{5}{|c|}{ 3. OLS results (2001-14) } \\
\hline $\mathrm{C}$ & -9.210341 & $-2 \mathrm{E}+07$ & 0 & \\
\hline LnPs & 1 & $1 \mathrm{E}+07$ & 0 & 170.264 \\
\hline LnPc & 4.23E-08 & 0.92626 & 0.3851 & 91.502 \\
\hline LnA & 1 & $1.7 \mathrm{E}+07$ & 0 & $4,281.024$ \\
\hline LnT & 1 & $4.1 \mathrm{E}+07$ & 0 & 59.475 \\
\hline LnSI & $-2.93 \mathrm{E}-08$ & -0.8165 & 0.4411 & 75.676 \\
\hline $\mathrm{LnV}$ & $-1.19 \mathrm{E}-08$ & -0.3229 & 0.7562 & $3,862.110$ \\
\hline $\mathrm{LnE}$ & $-1.82 \mathrm{E}-08$ & -1.2539 & 0.2501 & 3.012 \\
\hline $\mathrm{R}^{2}$ & 1.000 & & & \\
\hline Sig. & 0.000 & & & \\
\hline
\end{tabular}

As shown in Table 3, the multicollinearity of independent variables in the regression model was determined and then used to evaluate their variance inflation factor (VIF). The VIFs of variables were far greater than the maximum tolerance of 10 [29]. Coefficients of the regression model based on the OLS estimation had low 
credibility, and therefore they could not be used effectively to explain the factors influencing carbon emissions in Xinjiang.

In order to guarantee the accuracy of the regression model and overcome the influence of multicollinearity among variables on the regression coefficients, ridge regression was used to estimate the regression model [29]. Ridge regression can significantly reduce large standard errors among related independent variables [3536]. In this manner, acceptable biased estimates with smaller mean square errors can be obtained for related independent variables through bias-variance tradeoffs [29]. This is one of the most effective solutions for establishing the reliability of the regression coefficients. Using the ridge regression estimation based on Eq. (5), the ridge regression coefficient was selected according to the relationship between $\mathrm{R}^{2}$ and $\mathrm{K}$. When $\mathrm{K}=0.20$ (Stage 1952-77), $K=0.15$ (Stage 1978-2000), or $K=0.25$ (Stage 2001-14), $\mathrm{R}^{2}$ was almost stable. Thus, $\mathrm{K}=0.20$, $\mathrm{K}=0.15$, and $\mathrm{K}=0.25$ were selected for estimating the ridge regression coefficients shown in Table 4.

Before Reform and Opening-up (1952-1977):

$$
\begin{gathered}
\mathrm{LnI}=0.3074(\mathrm{LnPs})+0.0943(\mathrm{LnPc})+ \\
0.1270(\mathrm{LnA})+0.3841(\mathrm{LnT})+0.0959(\mathrm{LnSI}) \\
+0.0415(\mathrm{LnV})-0.0357(\mathrm{LnE})
\end{gathered}
$$

After Reform and Opening-up (1978-2000):

$$
\begin{gathered}
\mathrm{LnI}=0.2072(\mathrm{LnPs})+0.1114(\mathrm{LnPc})+ \\
0.2115(\mathrm{LnA})-0.1865(\mathrm{LnT})+0.0243(\mathrm{LnSI}) \\
+0.1997(\mathrm{LnV})-0.1037(\mathrm{LnE})
\end{gathered}
$$

Table 4. Ridge regression results of stages 1952-77, 1978-2000, and 2001-14.

\begin{tabular}{|c|c|c|c|}
\hline Parameters & $\begin{array}{c}\text { Stage } \\
1952-77\end{array}$ & $\begin{array}{c}\text { Stage } \\
1978-2000\end{array}$ & $\begin{array}{c}\text { Stage } \\
2001-14\end{array}$ \\
\hline $\begin{array}{c}\text { LnPs } \\
\text { (Population size) }\end{array}$ & 0.3074 & 0.2072 & 0.1935 \\
\hline LnPc (Urbanization) & 0.0943 & 0.1114 & 0.1966 \\
\hline $\begin{array}{c}\text { LnA } \\
\text { (Economic growth) }\end{array}$ & 0.1270 & 0.2115 & 0.2173 \\
\hline $\begin{array}{c}\text { LnT (Technological } \\
\text { progress) }\end{array}$ & 0.3841 & -0.1865 & -0.0857 \\
\hline $\begin{array}{c}\text { LnSI } \\
\text { (Industrialization) }\end{array}$ & 0.0959 & 0.0243 & 0.0219 \\
\hline $\begin{array}{c}\text { LnV (Fixed assets } \\
\text { investment) }\end{array}$ & 0.0415 & 0.1997 & 0.2413 \\
\hline $\begin{array}{c}\text { LnE (Energy } \\
\text { consumption } \\
\text { structure) }\end{array}$ & -0.0357 & -0.1037 & 0.0195 \\
\hline $\mathrm{R}^{2}$ & 0.9834 & 0.9921 & 0.9835 \\
\hline $\mathrm{K}$ (Ridge parameter) & 0.20 & 0.15 & 0.25 \\
\hline
\end{tabular}

Western Development (2001-2014):

$$
\begin{gathered}
\mathrm{LnI}=0.1935(\mathrm{LnPs})+0.1966(\mathrm{LnPc})+ \\
0.2173(\mathrm{LnA})-0.0857(\mathrm{LnT})+0.0219(\mathrm{LnSI}) \\
+0.2413(\mathrm{LnV})+0.0195(\mathrm{LnE})
\end{gathered}
$$

For the first period (1952-77), from the analysis of the regression results of Eq. (6), the main contributing factors promoting the growth of carbon emissions included population size (LnPs), urbanization ( $\mathrm{LnPc}$ ), economic growth (LnA), technological progress (LnT), industrialization (LnSI), and fixed assets investments $(\mathrm{LnV})$. The energy consumption structure $(\mathrm{LnE})$ alone showed an important negative effect on carbon emissions. The positive driving factors could be ranked according to their degree of influence: $\mathrm{LnT}>\mathrm{LnPs}>\mathrm{LnA}>\mathrm{LnSI}>\mathrm{LnPc}$ $>$ LnV. For the second period (1978-2000), from analysis of the regression results of Eq. (7), the major contributing factors for promoting carbon emissions growth included LnPs, LnPc, LnA, LnSI, and LnV. LnT and LnE played a significant role in curbing carbon emissions. The degree of positive influence of these factors in descending order is as follows: $\mathrm{LnA}>\mathrm{LnPs}>\mathrm{LnV}>\mathrm{LnPc}>\mathrm{LnSI}$. Factors with negative influence could be ranked according to their degrees of influence: LnT $>$ LnE. For the third period (2001-14), from the analysis of the regression results of Eq. (8) the major factors contributing to promotion of carbon emissions included LnPs, LnPc, LnA, LnSI, LnV, and LnE. Only LnT had a significantly negative effect on carbon emissions. The degree of positive influence in the descending order is as follows: $\mathrm{LnV}>\mathrm{LnA}>\mathrm{LnPc}>\mathrm{LnPs}$ $>$ LnSI $>$ LnE.

During 1952 to 1977 , LnT was the primary factor contributing to carbon emissions growth. This was due to extremely outdated production processes in which large amounts of energy were poorly utilized, and carbon emissions per unit GDP increased constantly. The relaxed population policy resulted in rapid population growth, which resulted in LnPs becoming the contributing factor promoting the increase in carbon emissions. LnA, LnPc, $\mathrm{LnSI}$, and $\mathrm{LnV}$ played relatively weak roles in promoting the increase in carbon emissions. The decline in the proportion of coal consumption led to $\mathrm{LnE}$ being the primary contributing factor to curbing carbon emissions; the proportion of coal consumption was adjusted with the fluctuation from $82.1 \%$ in 1952 to $74.2 \%$ in 1977 . After the Reform and Opening-up stage, promoting economic development became the priority. Xinjiang's economic development resumed rapid growth, making LnA the primary contributing factor to increasing carbon emissions. Nevertheless, LnPs remained an important factor contributing to the increase in carbon emissions after the two periods of birth peaks in the 1960s and 1970s. Owing to the full implementation of the policy for internal reforms and external opening-up, $\mathrm{LnV}$ increased rapidly. The effect of $\mathrm{LnV}$ promoting increases in carbon emissions clearly exceeded that of LnPc and LnSI. Meanwhile, with 
improvements in production processes and optimizations in the energy structure, the most important change was that carbon emissions per unit GDP declined rapidly. This shows a reversal from LnT being the primary factor contributing to increases in carbon emissions to becoming the primary factor curbing carbon emissions after 1978. Because the proportion of coal consumption decreased and the proportions of natural gas, hydropower, and wind power consumption increased, LnE remains the most important factor curbing carbon emissions in Xinjiang. During 2001 to 2014, the total amount of LnV in Xinjiang had been growing rapidly since the implementation of the national policy of "Western Development." Thus, LnV became the primary factor contributing to increases in carbon emissions after 2001. LnA remained the dominant factor driving the increase in carbon emissions. Owing to significant increases, LnPc was the third most significant factor contributing to increases in carbon emissions after 2001. Unfortunately, the proportion of coal consumption first decreased from $60.40 \%$ in 2001 to $56.10 \%$ in 2005 , but then increased to reach $65.1 \%$ in 2014 . LnE shows an obvious carbon-based trend of change, and its effects shifted from negative to positive. LnT remained the sole contributing factor curbing carbon emissions in Xinjiang because the carbon emissions per unit GDP continued to decline. Then the decline in carbon emissions per unit GDP slowed. The negative effect of LnT on the increase in carbon emissions was significantly weaker than that in the previous period from 1978 to 2000 , in absolute value.

\section{Conclusions}

An extended STIRPAT model based on the classical IPAT identity was used to determine the main factors driving energy-related carbon emissions in Xinjiang during 19522014. The impacts of various factors on carbon emissions varied among three different development stages: "Before Reform and Opening up" (1952-1977), “After Reform and Opening up" (1978-2000), and "Western Development" (2001-2014). Population size, economic growth, and fixed asset investments were the main factors contributing to increases in carbon emissions in Xinjiang during the three stages. Technological progress was the main factor contributing to curbing carbon emissions. The energy consumption structure had a significant negative effect on carbon emissions before 2000, and a positive effect after 2001. In the first stage, technological progress and population size were the two dominant positive contributors, while the energy consumption structure was the sole negative factor. In the second stage, economic growth and population size were the two dominant positive contributors, while technological progress had a significant negative effect. In the third stage, fixed assets investment and economic growth were the two dominant positive contributors, while only technological progress had a significant negative effect.

Solving these problems effectively will be of great help to Xinjiang in harmonizing economic growth and reducing carbon emissions, and possibly reducing environmental damage. Our findings, the main factors driving energyrelated carbon emissions in different development stages from a regional perspective, will provide an experiencebased reference for other regions at similar development stages.

\section{Acknowledgements}

This work was supported by the Xinjiang Laboratory of Lake Environment and Resources in the Arid Zone, Xinjiang Uygur Autonomous Region Key Laboratory Foundation (XJDX0909-2015-03), Xinjiang Normal University Doctoral Research Foundation (XJNUBS1538); the National Natural Science Foundation of China (41501144), the Guangdong Academy of Sciences Youth Science Foundation (qnjj201501), the High-Level Leading Talent Introduction Program of GDAS (2016GDASRC-0101), and the Scientific Platform and Innovation Capability Construction Program of GDAS (2016GDASPT-0210).

\section{References}

1. VALIPOUR M. Use of surface water supply index to assessing of water resources management in Colorado and Oregon, US. Advances in Agriculture, Sciences and Engineering Research, 3, 631, 2013.

2. VALIPOUR M. How Much Meteorological Information Is Necessary to Achieve Reliable Accuracy for Rainfall Estimations? Agriculture, 6, 53, 2016.

3. VALIPOUR M., GHOLAMI SEFIDKOUHI M.A., RAEINI-SARJAZ M. Selecting the best model to estimate potential evapotranspiration with respect to climate change and magnitudes of extreme events. Agricultural Water Management, 180, Part A, 50, 2017.

4. WANG C., WANG Q., WANG F. Is Vietnam Ready for Nuclear Power? Environmental Science \& Technology, 46, 5269, 2012.

5. MALAKOFF D. China's peak carbon pledge raises pointed questions. Science, 346, 903, 2014.

6. WANG C., WANG F., ZHANG H., YE Y., WU Q. China's Carbon Trading Scheme is a Priority. Environmental Science \& Technology, 48,13559,2014.

7. WANG C., WANG F., DU H., ZHANG X. Is China really ready for shale gas revolution-Re-evaluating shale gas challenges. Environmental Science \& Policy, 39, 49, 2014.

8. WANG C., WANG F., LI L., ZHANG X. Wake-up Call for China to Re-Evaluate Its Shale-Gas Ambition. Environmental Science \& Technology, 47, 11920, 2013.

9. TOLLEFSON J. US-China climate deal raises hopes for Lima talks. Nature, 515, 473, 2014.

10. WANG C., ZHANG X., WANG F., LEI J., ZHANG L. Decomposition of energy-related carbon emissions in Xinjiang and relative mitigation policy recommendations. Front Earth Sci, 9, 65, 2015.

11. WANG C., WANG F. Structural decomposition analysis of carbon emissions and policy recommendations for energy sustainability in Xinjiang. Sustainability, 7, 7548, 2015.

12. WANG C., WANG F., ZHANG H., YE Y., WU Q., SU Y. Carbon emissions decomposition and environmental 
mitigation policy recommendations for sustainable development in Shandong province. Sustainability, 6, 8164, 2014.

13. FENG K., HUBACEK K., GUAN D. Lifestyles, technology and $\mathrm{CO}_{2}$ emissions in China: $\mathrm{A}$ regional comparative analysis. Ecological Economics, 69, 145, 2009.

14. FENG K., DAVIS S.J., SUN L., LI X., GUAN D., LIU W., LIU Z., HUBACEK K. Outsourcing CO2 within China. Proceedings of the National Academy of Sciences, 110, 11654, 2013.

15. AL-MULALI U., FEREIDOUNI H.G., LEE J.Y., SAB C.N.B.C. Exploring the relationship between urbanization, energy consumption, and $\mathrm{CO}_{2}$ emission in MENA countries. Renewable and Sustainable Energy Reviews, 23, 107, 2013.

16. LIU W., LI H. Improving energy consumption structure: A comprehensive assessment of fossil energy subsidies reform in China. Energy Policy, 39, 4134, 2011.

17. KOFI ADOM P., BEKOE W., AMUAKWA-MENSAH F., MENSAH J.T., BOTCHWAY E. Carbon dioxide emissions, economic growth, industrial structure, and technical efficiency: Empirical evidence from Ghana, Senegal, and Morocco on the causal dynamics. Energy, 47, 314, 2012.

18. ZHENG Y., LUO D. Industrial structure and oil consumption growth path of China: Empirical evidence. Energy, 57, 336, 2013.

19. LI H., MU H., ZHANG M., LI N. Analysis on influence factors of Chinass $\mathrm{CO}_{2}$ emissions based on Path-STIRPAT model. Energy Policy, 39, 6906, 2011.

20. ZHANG Y.-J. The impact of financial development on carbon emissions: An empirical analysis in China. Energy Policy, 39, 2197, 2011.

21. ZHOU X., ZHANG J., LI J. Industrial structural transformation and carbon dioxide emissions in China. Energy Policy, 57, 43, 2013.

22. TIAN X., CHANG M., SHI F., TANIKAWA H. How does industrial structure change impact carbon dioxide emissions? A comparative analysis focusing on nine provincial regions in China. Environmental Science \& Policy, 37, 243, 2014.

23. LI H., MU H., ZHANG M., GUI S. Analysis of regional difference on impact factors of China's energy - Related $\mathrm{CO}_{2}$ emissions. Energy, 39, 319, 2012.

24. WANG C., WANG F., ZHANG X., ZHANG H. Influencing mechanism of energy-related carbon emissions in Xinjiang based on the input-output and structural decomposition analysis. Journal of Geographical Sciences, 27, 365, 2017.

25. EHRLICH P.R., HOLDREN J.P. Impact of population growth. Science, 171, 1212, 1971.

26. HOLDREN J.P., EHRLICH P.R. Human population and the global environment. American scientist, 62, 282, 1974.

27. YORK R., ROSA E.A., DIETZ T. Footprints on the Earth: The Environmental Consequences of Modernity. American Sociological Review, 68, 279, 2003.

28. YORK R., ROSA E.A., DIETZ T. STIRPAT, IPAT and ImPACT: analytic tools for unpacking the driving forces of environmental impacts. Ecological Economics, 46, 351, 2003.

29. WANG Z., YIN F., ZHANG Y., ZHANG X. An empirical research on the influencing factors of regional $\mathrm{CO}_{2}$ emissions: Evidence from Beijing city, China. Applied Energy, 100, 277, 2012.

30. VALIPOUR M. Analysis of potential evapotranspiration using limited weather data. Applied Water Science, 1, 2014.

31. REZAEI M., VALIPOUR M., VALIPOUR M. Modelling Evapotranspiration to Increase the Accuracy of the Estimations Based on the Climatic Parameters. Water Conservation Science and Engineering, 1, 197, 2016.

32. VALIPOUR M., ESLAMIAN S. Analysis of potential evapotranspiration using 11 modified temperature-based models. International Journal of Hydrology Science and Technology, 4, 192, 2014.

33. VALIPOUR M. Application of new mass transfer formulae for computation of evapotranspiration. Journal of Applied Water Engineering and Research, 2, 33, 2014.

34. AL-MULALI U., OZTURK I. The effect of energy consumption, urbanization, trade openness, industrial output, and the political stability on the environmental degradation in the MENA (Middle East and North African) region. Energy, 84, 382, 2015.

35. HOERL A.E., KENNARD R.W. Ridge Regression: Applications to Nonorthogonal Problems. Technometrics, 12, 69, 1970.

36. HOERL A.E., KENNARD R.W. Ridge Regression: Biased Estimation for Nonorthogonal Problems. Technometrics, 12, 55,1970 . 